\title{
COMPUTER SIMULATION OF THE ANGULAR DISTRIBUTION OF ELECTRONS AND BREMSSTRAHLUNG PHOTONS IN TANTALUM CONVERTER
}

\author{
DViktoriia V. Lisovska, (D)Tetiana V. Malykhina* \\ Kharkiv V.N. Karazin National University \\ 4, Svobody sq., 61022, Kharkiv, Ukraine \\ *Corresponding Author: malykhina@karazin.ua \\ Received 15 February 2020; revised March 12, 2020; accepted March 16, 2020
}

\begin{abstract}
The present work is dedicated to study of the possibilities of improving the production method of ${ }^{11} \mathrm{C}$ and ${ }^{18} \mathrm{~F}$ medical isotopes using a linear electron accelerator. Experimental studies of ${ }^{11} \mathrm{C}$ and ${ }^{18} \mathrm{~F}$ isotopes production by the photonuclear technique were carried out in [1]. Various targets were irradiated by bremsstrahlung photons following by measurements targets' activities. This experimental research has been carried out in the energy range from 10 to $40 \mathrm{MeV}$. The current work studies an angular distribution of bremsstrahlung photons in order to estimate the possibilities of producing maximum achievable levels of medical isotopes ${ }^{18} \mathrm{~F}$ and ${ }^{11} \mathrm{C}$ activities. The angular distribution of bremsstrahlung photons is an important property of the irradiation stand which contains an assembly of targets. This important property allows designing necessary changes in the target assembly setup used to produce medical isotopes. The research presented in the current work was done as a computer simulation. The computer software package 'KIPT' was developed in C++ programming language, using the Geant4 toolkit in order to obtain the angular distribution of bremsstrahlung photons. Experimental setup materials as well as structural elements positions were defined in the DetectorConstruction class of our program. The parameters of an electron beam were defined in the PrimaryGeneratorAction class. The electron beam diameter was defined as $8 \mathrm{~mm}$, energy $\mathrm{E}_{\mathrm{e}}=36.7 \mathrm{MeV}$, corresponding to the real experiment carried out at the "Accelerator" Science and Research Establishment of Kharkiv Institute of Physics and Technology [1]. Models of physical processes occurring while the electron beam crosses the target assembly were defined in the PhysicsList class. All classes and modules necessary for the analysis of simulation results were included to our program together with visualization modules. Visualization modules use the OpenGL graphics library and the Qt5 software to represent the relative position of experimental setup parts and to visualize particle trajectories. As a result of this work, the angular distributions were obtained for the beam of electrons and bremsstrahlung photons directly before the target. This result will allow target assembly parameter optimization for optimal production of medical isotopes by the photonuclear technique.
\end{abstract}

KEY WORDS: bremsstrahlung converter, angular distribution, Geant4 simulation, medical isotopes production

The use of radionuclides in nuclear medicine, biology as well as to assess the state of the environment and in other areas is widespread. Many nuclear centers have reactors or accelerators. These centers have technologies for the development and research of radionuclides producing methods. Radiopharmaceuticals created on the basis of these radionuclides make it possible to obtain information about pathological changes in various organs of a person after the injection of radiopharmaceuticals into the patient's body. At present, scientists of leading scientific centers conduct research on the production of radiopharmaceuticals by the photonuclear technique [1-3].

Scientists of Kharkiv Institute of Physics and Technology are conducting research in the field of photonuclear isotope production technique [1]. The target irradiation by bremsstrahlung flux is carried out to study the possibility of obtaining the maximum achievable activity levels of medical isotopes (in particular, ${ }^{11} \mathrm{C}$ and ${ }^{18} \mathrm{~F}$ ) using a linear electron accelerator. Further research is planned for development of radiopharmaceuticals based on these isotopes.

The use of computer simulation tools allows one to conduct a preliminary virtual experiment. This work is an assessment of the method of computer simulation of electrons and bremsstrahlung photons angular distributions for the experimental setup described in [1].

\section{FORMULATION OF THE PROBLEM}

Radioisotopes $\left({ }^{11} C\right.$ and $\left.{ }^{18} F\right)$ can be obtained as a result of photonuclear reactions ${ }_{z}^{A} X(\gamma, n){ }_{z}^{A-1} Y$ when using a linear electron accelerator. Lithium fluoride is used as a target in [1] to study the possibility of ${ }^{18} F$ production. Fluorine interacts with incident gamma rays, and final products are formed as a result of a nuclear reaction - the fluorine isotope ${ }^{18} F$ and a neutron:

$$
{ }_{8}^{19} F+\gamma \rightarrow{ }_{8}^{18} F+n .
$$

The energy of incident gamma rays must be above a threshold of $10.4 \mathrm{MeV}$ to obtain the fluorine isotope ${ }^{18} F$ [4]. Glucose $\mathrm{C}_{6} \mathrm{H}_{12} \mathrm{O}_{6}$ is used as the target for labeling with ${ }^{11} \mathrm{C}$ isotope. The carbon isotope ${ }^{11} \mathrm{C}$ is formed in the reaction

$$
{ }_{6}^{12} C+\gamma \rightarrow{ }_{6}^{11} C+n
$$

when glucose is irradiated by bremsstrahlung photons. The threshold of this nuclear reaction is $18.7 \mathrm{MeV}$ [4]. 
The target is placed in an aluminum capsule located immediately after the water-cooled bremsstrahlung converter. The bremsstrahlung converter consists of several layers of refractory metal with a large atomic number $z$ and atomic mass $A$. Tantalum was used in [1] as a suitable material with high density.

Incident electrons with initial energy $E_{e}=36.7 \mathrm{MeV}$ undergo multiple scattering while passing through the convertor. Thus bremsstrahlung photons from scattered electrons can be directed into larger cone than ones produced by only incident beam. Therefore, it is advisable to preliminarily estimate the angular distribution of produced gamma rays by a simulation method. Such simulation helps to estimate the optimal size of the aluminum capsule, which contains the target for the production of isotopes.

\section{RESEARCH METHODS}

The computer program that uses the Geant4-10.5 toolkit was designed to evaluate the angular distribution of bremsstrahlung photons in experiments on the production of radioisotopes by the photonuclear method.

The program contains definitions of the DetectorConstruction class, which describes materials of the necessary components of the real experimental setup [1], as well as their sizes and structural elements relative positions. Fig. 1 shows a simplified diagram of a simulated experiment.

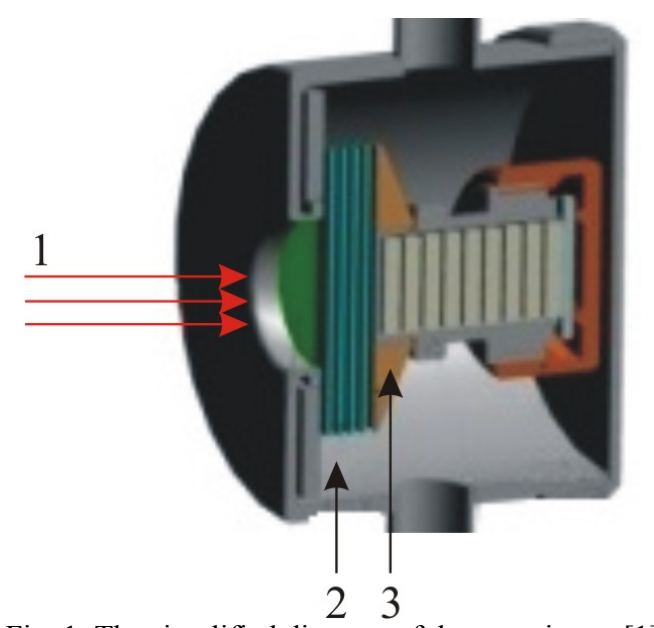

Fig. 1. The simplified diagram of the experiment [1]

1 - direction of primary electrons; 2 - bremsstrahlung converter; 3 - target

Important parameters of the primary electron beam are described according to the real experiment conditions in the PrimaryGeneratorAction class, which is a part of the program. The beam diameter is described using the G4UniformRand() method [5]. The beam diameter value is $8 \mathrm{~mm}$. The energy of primary electrons is described using the G4RandGauss::shoot method. The beam energy is $36.7 \mathrm{MeV}$. Models of all necessary physical processes that occur when an electron beam passes through a converter and target assembly are described in the PhysicsList class. The program also has all classes and modules necessary for the analysis of simulation results as well as visualization modules.

The PhysicsList class of our program describes physical processes using the Livermore model of low-energy electromagnetic processes. The Livermore low-energy electromagnetic process model implements the interaction of electrons and photons with matter down to energies of $250 \mathrm{eV}$. The Livermore model describes the following processes: photoelectric effect, Compton scattering, Rayleigh scattering, electron-positron pair formation, bremsstrahlung, and ionization. Realization of electromagnetic processes at low energies is valid for elements with atomic number up to 99 , and a minimal energy $10 \mathrm{eV}$ [6]. Data used to implement low-energy processes is collected in a set of evaluated data libraries, such as EEDL (Evaluated Electrons Data Library), EPICS2017 (Evaluated Photons Data Library) [4], etc. Multiple electron and positron scattering is implemented using the G4eMultipleScattering class and the G4GoudsmitSaundersonModel model. The G4GoudsmitSaundersonModel model was implemented in 2017, and today provides the best accuracy in the transport of electrons with energies below $100 \mathrm{MeV}$ [6]. Description of photonuclear processes in the PhysicsList model of our program contains a parameterization that uses the G4PhotoNuclearCrossSection class.

Figure 2 shows fragments of preliminary Geant 4 modeling in an interactive mode. This figure represents the OpenGL visualization of 10 electrons passage through one layer of $1 \mathrm{~mm}$ tantalum and $1 \mathrm{~mm}$ of water. The energy of electrons is $36.7 \mathrm{MeV}$. Primary electrons are directed at normal to the converter. The trajectories of electrons and bremsstrahlung photons are presented in Fig. 2 (a, b).

It is noticeable (Fig. 2) that electrons deviate from the original direction of motion even when passing through the first layer of tantalum. Therefore, bremsstrahlung photons are spread by some angle.

Computer simulation of the passage of 10000 primary electrons with an initial energy of $36.7 \mathrm{MeV}$ was carried out in a batch mode in order to analyze the bremsstrahlung photons angular distribution in details. Electrons and 
bremsstrahlung photons were monitored at the moment of crossing the target boundary. Coordinates of electrons and bremsstrahlung photons that crossed the target boundary with energies above the threshold were written to a file for further processing.
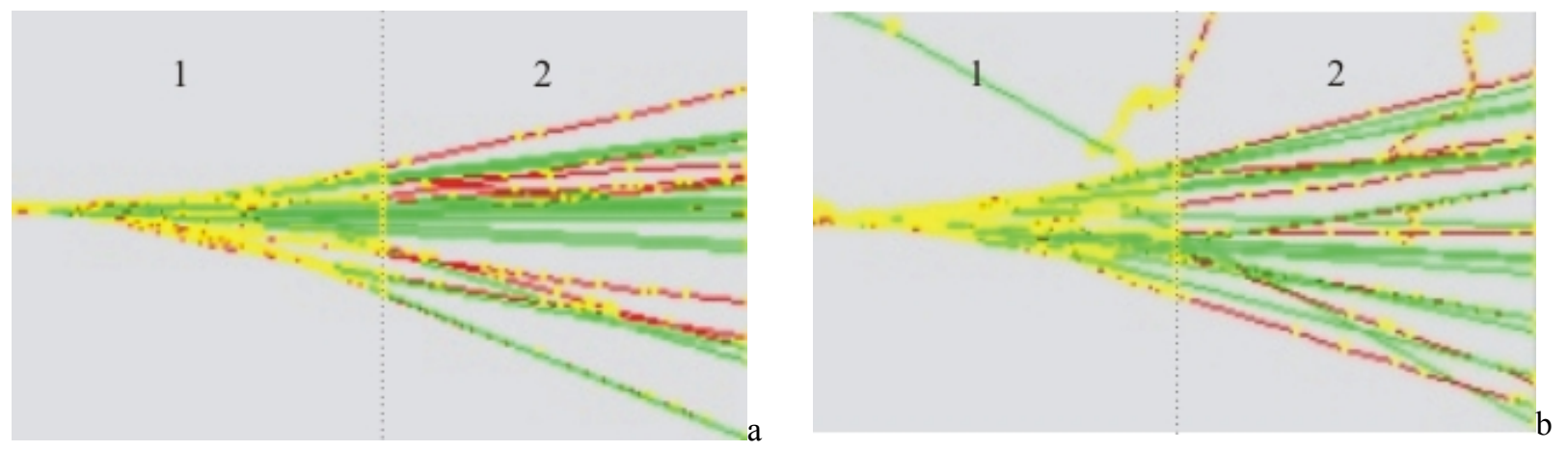

Fig. 2. The passage of 10 electrons with an energy of $36.7 \mathrm{MeV}$ through one layer of $1 \mathrm{~mm}$ tantalum and $1 \mathrm{~mm}$ of water: 1 - tantalum layer; 2 - water

Figure 3 shows the results of data processing of primary electrons (Fig. 3a and Fig. 3b) and bremsstrahlung photons (Fig. 3c and Fig. 3d) passage through four layers of the converter.

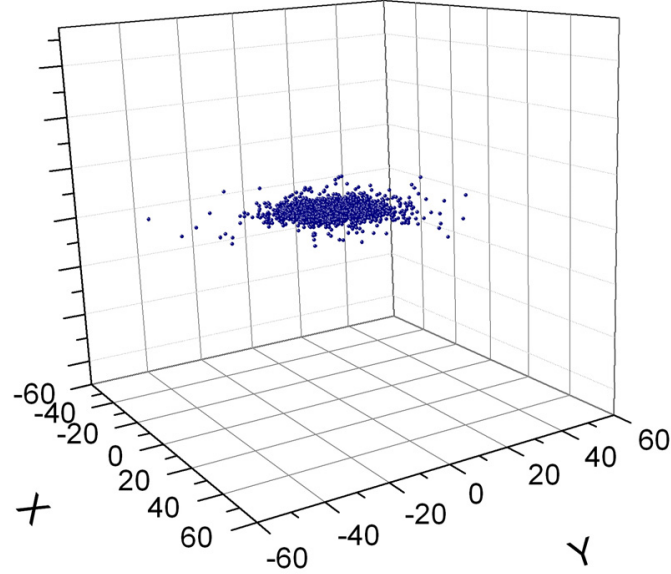

a

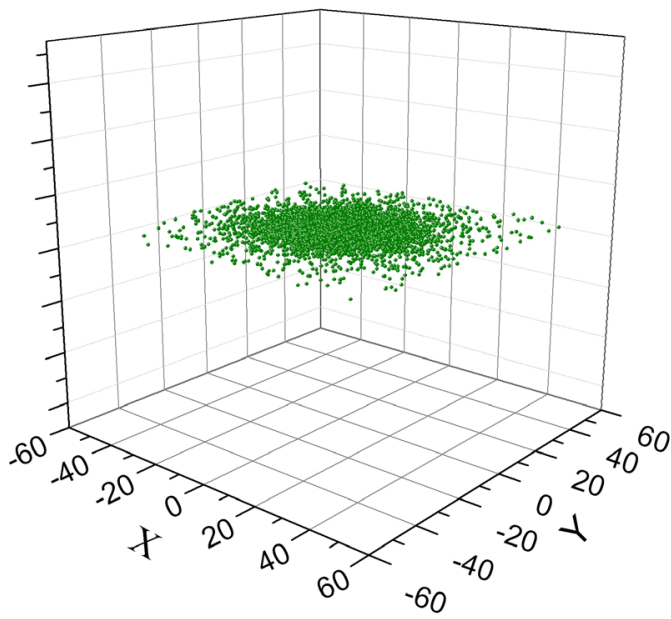

c

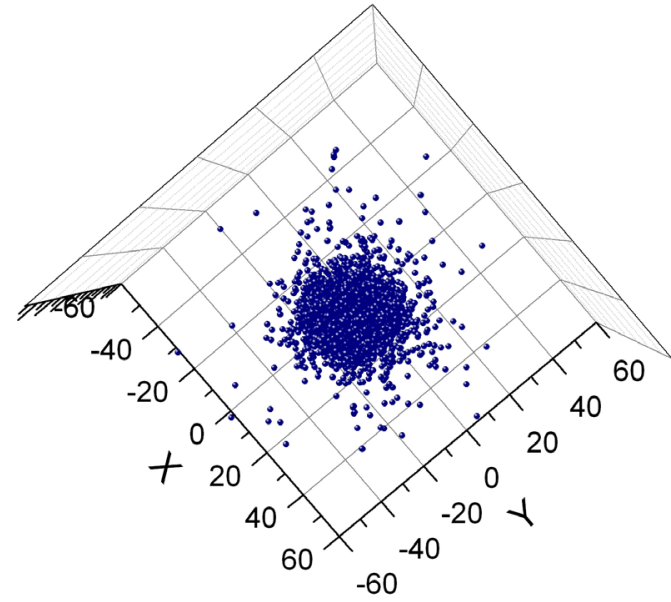

b

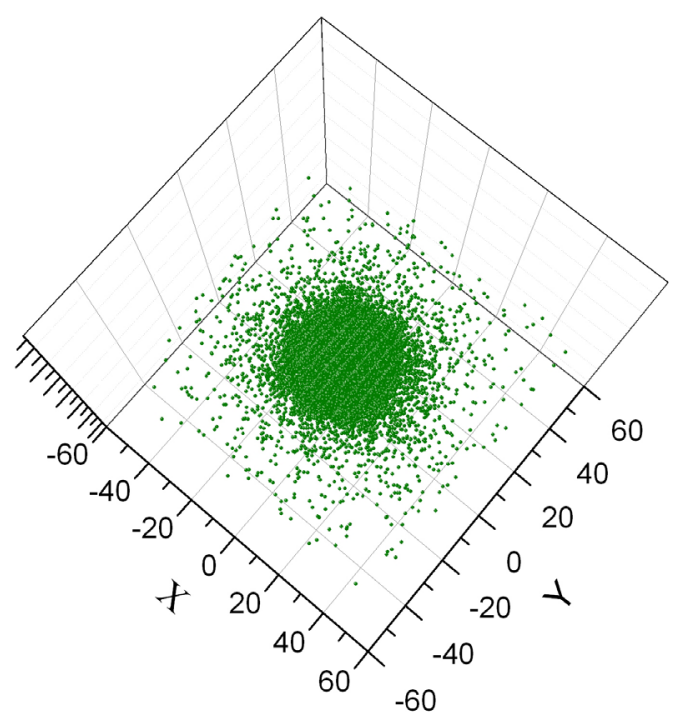

c

Fig. 3. The angular distribution of primary electrons (Fig. 3a and Fig. 3b) and bremsstrahlung photons (Fig. 3c and Fig. 3d) after passing through four layers of the converter 
Fig. $4 \mathrm{a}$ and Fig. $4 \mathrm{~b}$ present histograms obtained by calculating the frequency characteristics of the radii of the electron beam and bremsstrahlung photons after passing through four layers of tantalum and water. The graph does not show single events with radius values above $40 \mathrm{~mm}$.

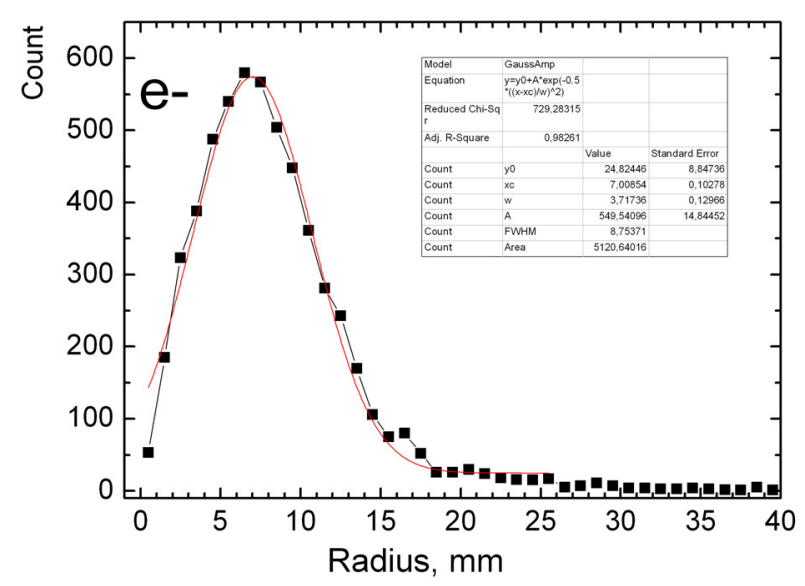

a

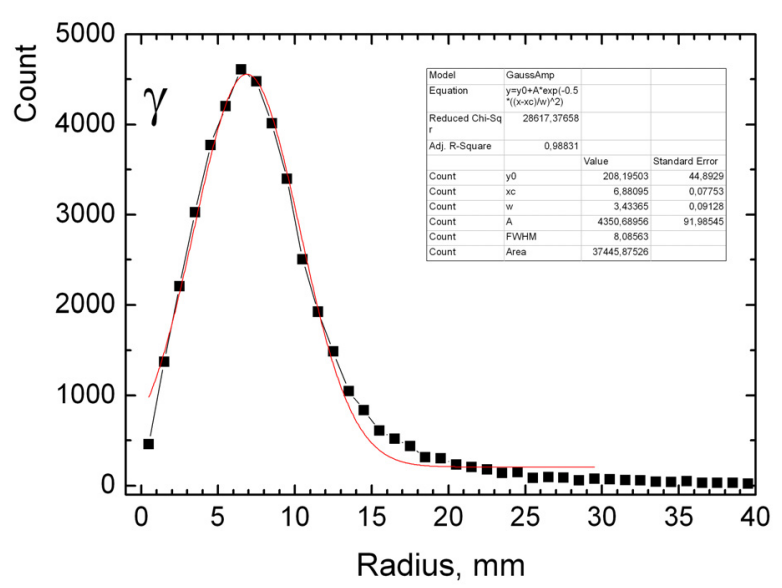

$\mathrm{b}$

Fig. 4. Frequency characteristics of the radii of the electron beam (a) and bremsstrahlung photons (b) after passing through 4 layers of tantalum and water

The most probable value of the scattering radius of bremsstrahlung photons was obtained as a result of processing the statistical data: $X_{C}=6.85 \mathrm{~mm}$, and $\sigma=3.2 \mathrm{~mm}$ (Fig. 4b). Therefore, there is a significant deviation of scatter radii of bremsstrahlung photons. We can obtain the value of the circle radius into which bremsstrahlung photons hit with a probability of $68 \%$ when crossing the capsule boundary using the "Three sigma rule" [7]:

$$
3.65 \mathrm{~mm} \leq R \leq 10 \mathrm{~mm} \text {. }
$$

Therefore, the maximum probability diameter of the bremsstrahlung photons scatter circle is $20 \mathrm{~mm}$. This means that the capsule containing the target must have a diameter of at least $20 \mathrm{~mm}$ if located directly behind the tantalum converter.

A series of virtual nuclear physical experiments are being conducted to determine the ${ }^{18} \mathrm{~F}$ and ${ }^{11} \mathrm{C}$ isotope yeild after increasing the diameter of the target to $20 \mathrm{~mm}$.

\section{CONCLUSION}

As a result of the work, the angular characteristics of the primary electrons beam and bremsstrahlung photons directly in front of the target were obtained. This allows optimal placement of the target assembly for the medical isotopes production by the photonuclear method. It was found that the maximum diameter of the circle into which bremsstrahlung photons hit with a probability of $68 \%$ when crossing the target boundary is $20 \mathrm{~mm}$. Consequently, with the increase of the target diameter from $10 \mathrm{~mm}$ [1] to $20 \mathrm{~mm}$, it will be possible to increase the activity level of medical isotopes due to more proper size of the target.

DViktoriia V. Lisovska, https://orcid.org/0000-0003-1237-7959

\section{ORCID IDs}

(D) Tetiana V. Malykhina, https://orcid.org/0000-0003-0035-2367

\section{REFERENCES}

[1] A.N. Dovbnya, R.N. Dronov, V.A. Kushnir, V.V. Mitrochenko, S.A. Perezhogin, L.I. Selivanov, V.A. Shevchenko, and B.I. Shramenko, East Eur. J. Phys. 4, 77-86 (2018), https://doi.org/10.26565/2312-4334-2018-4-09.

[2] M. Fujiwara, K. Nakai, N. Takahashi, T. Hayakawa, T. Shizuma, S. Miyamoto, G.T. Fan, A. Takemoto, M. Yamaguchi, and M. Nishimura, Physics of Particles and Nuclei, 48(1), 124-133 (2017), https://doi.org/10.1134/S1063779617010075.

[3] D. Nabs, and U. Köster, Applied Physics B, 103(2), 501-519 (2011), https://doi.org/10.1007/s00340-010-4278-1.

[4] Geant4 Collaboration, Book For Application Developers Release 10.5, https://geant4-userdoc.web.cern.ch/geant4userdoc/UsersGuides/ForApplicationDeveloper/BackupVersions/V10.5-2.0/fo/BookForApplicationDevelopers.pdf.

[5] Geant4 Collaboration, Physics Reference Manual, https://geant4-userdoc.web.cern.ch/geant4userdoc/UsersGuides/PhysicsReferenceManual/BackupVersions/V10.5-2.0/fo/PhysicsReferenceManual.pdf

[6] NEA: Electron photon interaction cross section library. https:/www.oecd-nea.org/tools/abstract/detail/iaea1435/

[7] V.M. Kalinin, S.R. Tikhomirov, Lectures on Theory of Probability and Mathematical Statistics, (Saint-Petersburg State Institute of Technology, 2002), pp. 90. (in Russian) 


\title{
КОМП'ЮТЕРНЕ МОДЕЛЮВАННЯ КУТОВОГО РОЗПОДІЛУ ЕЛЕКТРОНІВ \\ ТА ГАЛЬМІВНИХ ГАММА-КВАНТІВ У ТАНТАЛОВОМУ КОНВЕРТОРІ
}

\author{
В.В. Лісовська, Т.В. Малихіна
}

Харківський національний університет імені В.Н. Каразіна

майдан Свободи, 4, 61022, Харків, Украӥна

Представлена робота присвячена дослідженню можливості удосконалення методів отримання медичних ізотопів ${ }^{11} \mathrm{C}$ та ${ }^{18} \mathrm{~F}$ iз використанням лінійного прискорювача електронів. У роботі [1] проводилися експериментальні дослідження напрацювання фотоядерним способом ізотопів ${ }^{18} \mathrm{~F}$ та ${ }^{11} \mathrm{C}$ у різних мішенях при опроміненні потоком гальмівного випромінювання цільових мішеней. Експериментальні дослідження проведені в діапазоні енергій від $10 \mathrm{MeB}$ до $40 \mathrm{MeB}$. У представленій роботі проводяться дослідження кутового розподілу гальмівних гамма-квантів 3 метою з'ясування можливостей отримання максимально досяжних рівнів активності медичних ізотопів ${ }^{18} \mathrm{~F}$ та ${ }^{11} \mathrm{C}$. Кутовий розподіл гальмівних гамма-квантів $\epsilon$ важливою характеристикою випромінювального стенду, що містить збірку цільових мішеней, тому що знання цих важливих параметрів дозволяє внести необхідні зміни до конструкції збірки мішеней для напрацювання медичних ізотопів. Дослідження, представлені в даній роботі, виконувалися засобами комп'ютерного моделювання. Для вирішення задачі про кутовий розподіл гальмівних гамма-квантів була розроблена комп'ютерна програма КIPT мовою С++ 3 використанням бібліотеки класів Geant4. Програма містить визначення класу DetectorConstruction, в якому описуються матеріали необхідних складових елементів реальної експериментальної установки, а також взаємне розташування всіх елементів конструкції. У класі PrimaryGeneratorAction, що входить до складу програми, описані параметри пучка первинних електронів. Діаметр пучка електронів дорвінює 8 мм, енергія $\mathrm{E}_{\mathrm{e}}=36.7 \mathrm{MeB}$, відповідно до умов реального експерименту, проведеного в Науково-дослідному комплексі «Прискорювач» ННЦ ХФТІ [1]. У класі PhysicsList описувалися моделі фізичних процесів, що відбуваються при проходженні пучка електронів через мішень. Програма також містить всі класи $\mathrm{i}$ модулі, необхідні для аналізу результатів моделювання, а також модуль візуалізації. Модулі візуалізації використовують графічну бібліотеку OpenGL, а також програмний сервіс Qt5 для більш наочного уявлення взаємного розташування елементів експериментальної установки і візуалізації траєкторій електронів, позитронів, гамма-квантів. У результаті виконання роботи отримані кутові характеристики пучка первинних електронів і гальмівних гамма-квантів безпосередньо перед цільовою мішенню, що дозволить оптимізувати параметри збірки цільових мішеней для напрацювання медичних ізотопів фотоядерним способом.

КЛЮЧОВІ СЛОВА: конвертер гальмівного випромінювання, кутовий розподіл, Geant4-моделювання, виробництво медичних ізотопів

\section{КОМПЬЮТЕРНОЕ МОДЕЛИРОВАНИЕ УГЛОВОГО РАСПРЕДЕЛЕНИЯ ПЕРВИЧНЫХ ЭЛЕКТРОНОВ И ТОРМОЗНЫХ ГАММА-КВАНТОВ В ТАНТАЛОВОМ КОНВЕРТЕРЕ}

\section{В.В. Лисовская, Т.В. Малыхина}

Харьковский национальный университет имени В.Н. Каразина майдан Свободыl, 4, 61022, Харьков, Украина

Данная работа посвящена исследованию возможности усовершенствования методов получения медицинских изотопов ${ }^{11} \mathrm{C}$ и ${ }^{18} \mathrm{~F}$ с использованием линейного ускорителя электронов. В работе [1] проводились экспериментальные исследования наработки фотоядерным способом изотопов ${ }^{18} \mathrm{~F}$ и ${ }^{11} \mathrm{C}$ в различных мишенях, при облучении потоком тормозного излучения целевых мишеней. Экспериментальные исследования проведены в диапазоне энергий от 10 МэВ до 40 МэВ. В представленной работе проводятся исследования углового распределения тормозных гамма-квантов с целью выяснения возможностей получения максимально достижимых уровней активности медицинских изотопов ${ }^{18} \mathrm{~F}$ и ${ }^{11} \mathrm{C}$. Угловое распределение тормозных гамма-квантов является важной характеристикой облучательного стенда, содержащего сборку целевых мишеней, т.к. знание этих важных параметров позволяет внести необходимые изменения в конструкцию сборки мишеней для наработки медицинских изотопов. Исследования, представленные в данной работе, выполнялись средствами компьютерного моделирования. Для решения задачи об угловом распределении тормозных гамма-квантов была разработана компьютерная программа KIPT на языке C++ с использованием библиотеки классов Geant4. Программа содержит определения класса DetectorConstruction, в котором описываются материалы необходимых составных элементов реальной экспериментальной установки, а также взаимное расположение всех элементов конструкции. В классе PrimaryGeneratorAction, входящем в состав программы, описаны параметры пучка первичных электронов. Диаметр пучка электронов был задан 8 мм, энергия $\mathrm{E}_{\mathrm{e}}=36.7 \mathrm{MэB}$, согласно условиям реального эксперимента, проводимого в Научноисследовательском комплексе «Ускоритель» ННЦ ХФТИ [1]. В классе PhysicsList описывались модели физических процессов, происходящих при прохождении пучка электронов через сборку мишеней. Программа также содержит все классы и модули, необходимые для анализа результатов моделирования, а также модуль визуализации. Модули визуализации используют графическую библиотеку OpenGL, а также программный сервис Qt5 для более наглядного представления взаимного расположения элементов экспериментальной установки и визуализации траекторий электронов, позитронов, гамма-квантов. В результате выполнения работы получены угловые характеристики пучка первичных электронов и тормозных гамма-квантов непосредственно перед целевой мишенью, что позволит оптимизировать параметры сборки целевых мишеней для наработки медицинских изотопов фотоядерным способом.

КЛЮЧЕВЫЕ СЛОВА: конвертер тормозного излучения, угловое распределение, Geant4-моделирование, производство медицинских изотопов 